\title{
Discussion on the Ways to Practical Teaching Information of Accounting Major in the Internet + Era
}

\author{
Jiang Xuesong, Xu Lu, Xiao Nanyun \\ ${ }^{1}$ Harbin University of Commerce, Harbin, 150000, China \\ ${ }^{2}$ Harbin Finance University, Harbin, 150000, China
}

Keywords: Internet+; Accounting Major; practical teaching information

Abstract: "Internet +" is a new form of Internet development. It combines information technology and accounting major teaching closely. By discussing the way to practical teaching information of Accounting Major, the teaching resources, teaching methods and teaching modes will be continuously innovated, then we will open up a new space for the practical teaching of Accounting Major.

\section{互联网+时代会计学专业实践教学信息化途径探讨}

\author{
姜雪松 ${ }^{1}$, 徐鹿 ${ }^{1, *}$, 肖南云 ${ }^{2}$ \\ ${ }^{1}$ 哈尔滨商业大学, 哈尔滨 黑龙江省 中国 150000 \\ ²哈尔滨金融学院，哈尔滨 黑龙江省 中国 150000
}

关键词: 互联网+；会计学专业；实践教学信息化

摘要: “互联网+”是互联网发展的新业态, 互联网+使信息技术同会计学专业教学紧密结合。 通过对会计学专业实践教学信息化途径的探讨, 使教学资源、教学方法、教学模式不断创新, 为会计学专业实践教学开辟了新的拓展空间。

“互联网+”是知识社会在创新 2.0 推动下的互联网形态演进及其催生的经济社会发展新形 态。在这个崭新的时代，信息技术对传统会计理论、实务和教学都产生着巨大的变革性影响。

实践教学是培养应用型人才的必由之路，也是提升学生就业力的保障。一直以来，国内相 关学者对会计学专业的实践教学都进行了积极的探索, 形成了较为稳定的实践教学体系。但 是, 实践教学的具体实施效果并不理想, 说明当前会计学专业实践教学体系还存在很大弊端。 通过对会计学专业实践教学信息化途径的探索, 不但能培养学生的动手能力, 还可以强化学 生分析问题和解决问题的能力, 使其成为一名合格的会计人员。不断向社会输送高质量的会 计人才。

\section{1. 引言}

社会在不断进步, 经济持续快速增长, 带动了社会对会计人才需求的不断增加。据统计, 全国近 1200 所高等院校中都设有会计学专业, 高等学校每年培养的会计学专业毕业生超过 50 万人。企业需要的会计人才应具有一定的实践经历和经验, 而绝大部分的会计学专业的应 届毕业生因不具备实践能力而被企业拒收。教育部、财政部等部门下发的《关于实施高等学 校本科教学质量与教学改革工程的意见》中强调“高度重视实践环节，提高学生实践能力。” 
充分说明高等学校实践教学对提高学生综合素质和实际操作水平的重要性。会计学是一门操 作性很强的经济管理应用学科, 会计学专业的实践教学要求学生在掌握会计理论和方法的基 础之上, 能够熟练的运用所学的知识进行实践操作。

\section{2. 互联网+时代会计学专业实践教学信息化的必要性}

伴随着互联网+时代的到来, 会计学专业实践教学也应适应时代要求而进行改革创新。

\section{1 互联网+时代教学资源、教学手段更加丰富}

移动互联网的发展为实践教学提供了更加丰富的资源。海量 PPT 模板, 使课堂 PPT 制作精 彩纷呈; 大量的真实案例, 使课堂教学更加生动; 精品课程网站、微课网站等学习网站提供 了丰富的教案、讲义、视频等资源。社交媒体为学习者提供了信息交流与共享的平台，每个 人都可以是信息的发起者、接受者、传播者。软件开发企业为推广自己的产品, 为教师、学 生提供软件的试用版，使学校支付更少的钱获得更多的实习、实训服务，为学生提供更多的 实训机会;学生通过自己的操作, 获得了更多的自己探索学习的机会, 同时也获得了更少的灌 输与更多的交流探讨。网络架起了人与人沟通交流的桥梁, 为会计学专业实践教学教学提供 了更加便利的条件。

\section{2 互联网+时代教学方法更加灵活}

互联网+时代, 教学方法已不再是是单纯的粉笔+黑板。得益于互联网技术的发展, 教学也 进入了新媒体时代, 各种音频、视频教学资源遍布网络, 使我们的教学方法更加灵活。当前, 智能手机已成为人们必不可少的联系、沟通、学习的重要工具。学生使用手机的频率更加频 繁, 因此, 可以利用学生的碎片化时间学习; 课堂上让学生查找相关的学习资料, 引导学生 正确、合理的使用手机。

\section{3 互联网+时代教学模式不断创新}

当前, 移动互联网技术已经深入我们的生活、学习中, 改变了我们的生活、学习方式, 也 使教学模式不断创新。慕课课程可以整合多种社交网络工具和多种形式的数字化资源, 形成 多元化的学习土具和丰富的课程资源; 同时, 它突破传统课程时间、空间的限制, 更能适应 学生的个性化需求, 随时随地都可以学习; 依托互联网, 世界各地的学习者足不出户就可学 到国内外顶级名校课程。微课, 即微课程, 是在较短的时间内以视频为主要载体, 记录课堂 教学中某个知识点的教学, 或是反映课堂教学环节、教学主题的教与学活动。具有时间短、 课程内容重点突出、内容更具体、针对性更强等特点, 适应学生利用碎片化时间学习, 更好 的满足了学生的个性化需求, 深受学生欢迎。这些教学模式的创新丰富了会计学专业实践教 学的手段、方法。

\section{3. 高等院校会计学专业实践教学体系中存在的问题}

\section{1 实践教学的理念溃泛。}

有些高校仅仅将实践教学作为传统理论教学的辅助手段, 从而降低了实践教学在课堂教育 中的重要性。有些高校的教学还是以理论教育为中心, 实践教学的功能无法发挥出来。同时, 高校会计学专业的教师往往都是毕业后直接被校方聘用, 没有企业中的实际经验, 对从事会 计职业的内容、技能等缺乏切身体会。教学活动中理论篇幅过多, 内容无法做到与时俱进, 与社会的实际需求有一定的距离, 所教授的内容无法满足会计岗位的真实需求。很多高校也 缺乏对就业市场环境对会计专业学生需求变化情况的关注, 不注重根据市场需求变化灵活调 整教学培养方案, 使理论与实际应用无法对接。 


\section{2 实践教学体系不合理, 缺乏有效的考核指标}

当前, 很多院校由于对实践教学重视不够, 导致人才培养方案制定不科学, 前后课程不衔 接, 没有层次划分。有的学校在没有开设相关理论课程的基础上, 就要求学生上实训课; 很 多校内实训课就被等同于习题课, 即使是上机实训, 也不过是把书本上的题搬到了电脑上做, 仍然是以老师讲授为主, 课程内容、组织形式没有新意。没有理论基础, 实训课无法达到预 期效果, 实践教学体系设计不合理。同时, 专业实践课程没有具体的考核指标, 无论是课内 实训还是毕业实习都是学生写实验报告, 老师随意给分, 课程就结束了, 至于有没有达到教 学目标, 实现教学效果, 学生有没有真正掌握相关的知识, 具备相应岗位具备的能力, 没有 具体的衡量标准。缺乏有效的考核指标, 影响了实践教学的有效开展, 导致实践教学效果不 理想。

\section{3 实践教学的设施落后, 校外实习流于形式。}

会计学专业是一门实践性很强的学科, 需要配置较高的教学辅助设施。但是, 有些高校的 基础设施建设落后、教学资源匾乏; 同时, 受传统教学思维模式的影响, 许多高校重理论轻 实践，因而实践教学投入资金严重不足，硬件设备缺乏，难以满足多个教学班同时开设一门 课程; 而软件投入不足更为严重。实践教学设施落后, 影响了实践教学的有效开展。大多数 会计学专业的校外实习流于形式。虽然与企业签订了实习基地协议, 但由于企业害怕商业机 密泄密, 学校的经费不足, 协议仅仅限于书面合作; 并没有把“教学一实习一生产实践”真正 结合起来, 无法为学校学生提供数量稳定的实习机会。

\section{4 实践教学师资队伍整体素质不高, 影响实践教学效果}

担任高校会计学专业的实践教学教师应该具备扎实的理论基础和丰富的实践经验，才能指 导学生实训、实习的工作。但是, 很多高校会计学专业的教师还在沿用传统的教学方法, 以 课堂授课为主, 不重视对会计职业的实践能力的培养。多会计专业教师本身没有在企业的实 际工作经验, 直接由学校毕业后来校任教, 其自身的实践应用能力还较差, 再去培养学生的 实践应用能力, 其教学效果自然很差。有些高校对教师岗位的设计也不合理, 将会计教师划 分为理论教育教师与实践教育教师, 由于实践型教师的工资低，一些高素质的人才都不愿意 去从事实践层面的教学, 使得实践型教师队伍发展缓慢。

\section{4. 互联网+时代实现会计学专业实践教学信息化的途径}

\section{1 建立基于互联网+时代的会计学专业实践教学体系}

信息化教学模式能够最大化的开发并引导学生自主学习的发挥。基于“互联网+”时代的会计 学专业教学强调教学过程的实践性, 而这种实践性教学必须具有明确的实践方向。所以, 会 计学专业实践教学信息化在实际应用中必须与会计职业环境相对应, 针对会计实际工作岗位 要求来设计实践内容。一个完整的会计实践教学体系应该包括:基础技能实训; 单项实训, 即基本岗位技能的实训，如出纳岗位技能实训、会计基本技能实训、成本会计基本技能实训、 纳税筹划基本实训等; 综合实训, 以仿真实训为基础, 集手工、会计电算化、财务、税务等 为一体的会计综合实训；定岗实习、校外实习。

\section{2 建立高校会计学专业实践教学信息化评价机制}

教学评价机制在高校会计学专业实践教学信息化模式中具有重要的辅助性作用。通过对教 学过程中学生的表现来对学生的知识形成过程进行分析与评估, 进而为实践教学信息化模式 的调整和优化提供的参考依据。传统的实践教学教学评价只是简单的对学生考试成绩进行评 价, 根据最终考试成绩结果来对教师教学能力以及学生知识水平进行定论这种方式容易误导 学生以成绩作为学习导向, 而创新高校会计学专业实践教学信息化评价机制专注于学生的自 主学习能力的发挥。而且, 这种考评方法能够帮助学生建立起学习的自信心和积极性, 对会 
计课程的后续教学活动具有重要的推动性作用。实践教学信息化评价机制能够利用网络实践 教学平台的技术性, 对学生的学习行为进行全面而精准的监督与统计, 并通过一定的统计学 方法来对学生进行公正而客观的评价。

\section{3 采用信息化手段提升教师实践教学水平}

教育信息化的过程中, 作为信息化教学工具使用者的教师是及其重要的环节、实践教学水 平的提升离不开教师教学能力的增强。在实施信息化教学的过程中, 要把实践教学师资培训 放在重要位置。可以借助信息化和网络技术平台, 让教师学习新理念、新教学和新技术, 鼓 励教学能手、教学骨干和信息技术爱好者的互助合作, 加强课程与信息技术的整合, 促进教 师利用信息技术提升教学能力和实践水平。同时要注意避免重硬件、轻软件和轻人才培养, 通过加强教师的培训力度, 提高信息技术应用能力。

\section{5. 结语}

会计学专业实践教学的改革是会计教学研究中的重要内容。互联网+时代为会计学专业实 践教学的改革既带来了机遇也带来了一定的挑战。高校应该充分利用互联网提供的丰富资源, 不断创新教学方法、教学模式, 建立符合本科人才培养要求的实践教学体系, 更加精准的开 展实践教学活动, 加强实践教学效果的跟踪与反馈, 不断提高高校会计学专业的实践教学水 平。

\section{[参 考 文 献]}

[1] 唐欣, 康健.基于卓越人才培养的地方院校会计实践教学改革探析[J].财会学习.2016(1): $253+255$.

[2] 谭敏, 谭灵. 关于实践教学视角下的本科会计教学方法改革 [J]. 财经界 (学术版). 2016(2):148+235.

[3] 刘丽娟.互联网+时代会计专业实践教学改革研究[J].农村经济与科技.2016 年(12): 260-261.

[4] 武剑锋.互联网+时代的中级财务会计实践教学改革研究[J].人力资源管理.2017(1): 170-171.

[5] 何丹, 吴芝霖.创新型会计国际化人才实践教学模式研究[J].财会月刊.2014(14): 113-117. 